\title{
Calibration of Short-Duration Stimuli Used in Auditory Evoked Potentials
}

\author{
Jin-Dong Kim \\ Department of Speech and Hearing Therapy, College of Health Science, Catholic University of Pusan, Busan, Korea
}

\begin{abstract}
청성유발전위를 기록하는 데 사용되는 단기지속 자극음의 교정
\end{abstract}
김 진 동

부산가톨릭대학교 보건과학대학 언어청각치료학과

\begin{abstract}
Auditory evoked potentials (AEPs) are measured for auditory threshold estimation and neuro-otologic assessment and are generally evoked by short-duration signals. The purpose of this paper is to provide information about the calibration of short-duration stimuli for the recording of AEPs. Since there are no national standards concerning the measurement of short-duration stimuli, calibration of shortduration stimuli are introduced in reference to the newest version of international standards. Especially, the behavioral and physical calibration of clicks and tone-bursts used in the AEP system for early AEPs are focused on and explained. Two of the recent international standards (IEC 60645-3:2007, ISO 389-6:2007) can help to guide the calibration of short-duration stimuli. In these standards, the reference equivalent threshold sound pressure levels based on the peak-to-peak equivalent sound pressure level (p-p.e.SPL) is defined as the calibration value of clicks and tone-bursts. We need to quantify the level of short-duration stimuli using the p-p.e.SPL approach. However, some researchers have found that even these standards are still lacking or inadequate. This paper will provide useful information about the calibration of short-duration stimuli to technicians and audiologists who regularly check the AEP system. It is also important to understand additional measures (peak SPL, baseline-to-peak equivalent SPL) for quantifying short-duration stimulus levels.
\end{abstract}

Key Words: Auditory evoked potentials, Short-duration stimuli, Peak-to-peak equivalent sound pressure level, Behavioral calibration, Physical calibration.

Received: September 25, 2017 / Revised: November 2, 2017 / Accepted: November 3, 2017

Correspondence: Jin-Dong Kim, Department of Speech and Hearing Therapy, College of Health Science, Catholic University of Pusan, 57 Oryundae-ro, Geumjeong-gu, Busan 46252, Korea

Tel: +82-51-510-0844 / Fax: +82-51-510-0848 / E-mail: jdkim@cup.ac.kr

\section{INTRODUCTION}

청각전문가는 부정확한 진단, 부적절한 권고, 불필요한 의뢰 로 이어질 수 있는 청력검사결과의 오류를 예방하기 위해 자신 이 사용하고 있는 모든 종류의 청각검사장비가 올바르게 작동 하고 있는지 여부를 최우선적으로 확인해야 한다. 일반적으로 청력검사는 인간의 청취 능력을 직·간접적으로 파악하기 위해 순음, 어음, 잡음과 같은 장기지속신호(long-duration signal, $>200 \mathrm{msec}$ )와 클릭음(clicks) 톤 버스트(tone-bursts)[단음 (brief-tone) 또는 톤 핍(tone pip)], chirps, 옥타브 대역(octaveband) chirps 등과 같은 단기지속신호(short-duration signal, $<200 \mathrm{msec}$ )[또는 일과성음향신호(acoustic transients)] 등의 다양한 음향신호를 이용한다. 따라서 청력검사장비의 교정은
청력검사용 음향신호가 이미 알려져 있는 기준 값에 부합되는 지 또는 관련 표준을 충족하고 있는지에 관한 종합적인 평가이 다. 청력검사장비의 교정은 청각검사장비의 판매 대리점에 소속 된 기술자가 수행하는 경우가 대부분이지만, 적절한 장비와 자 원을 구비하고 있는 경우 청각전문가는 스스로 청력검사장비의 교정을 수행하는 것이 더 바람직할 것이다. 이를 위해 청각전문 가는 청력검사장비의 다양한 출력장치를 통해 생성된 검사신호 를 점검하는 전기음향학적 교정을 잘 이해해야 한다. 순음청력 검사기의 경우 순음의 출력강도, 선형성(linearity)뿐 아니라 주 파수 정확도, 왜곡, 상승 및 하강 시간과 같은 다양한 종류의 다 른 변수에 대해서도 점검해야 하며(Kim, 2016a), 어음청력검사 기의 경우 감시계(monitoring meter), 어음신호의 출력강도, 주파 수 반응, 재생장치 등을 추가적으로 점검해야 한다(Kim, 2016b). 
이미턴스 장비의 경우 음향 이미턴스 분석 시스템, 프로브 신호, 공기역학 시스템, 음향반사활성화 신호 등을 점검해야 한다 (Kim, 2016c). 또한 하드웨어의 연결 문제, 케이블의 마모 또는 손상, 다이얼 또는 버튼의 작동 이상, 검사신호의 간헐성(intermittency), 잡음 등을 확인하기 위해 듣기 점검 및 생물학적 점 검(biologic check)을 실시한다.

청성유발전위(auditory evoked potentials, AEPs)는 청각역 치 추정 및 이신경학적 평가(neuro-otologic assessment)를 위 해 측정하며, 일반적으로 지속시간이 짧은 단기지속신호로 유 발된다. 단기지속신호로 가장 많이 사용되는 두 종류의 음향 자극음은 클릭음 및 톤 버스트이다. 청성유발전위 시스템에서 지원하는 단기지속신호는 제조회사에 따라 다소 차이가 있지 만, 모든 종류의 유발전위 시스템은 클릭음 및 톤 버스트를 자체 적으로 생성할 수 있다. 클릭음은 일과성 음향 또는 진동 신호로 출력장치의 종단부에 지속시간이 짧은 전기 사각펄스를 적용하 여 생성되는 넓은 범위의 주파수 스펙트럼을 가지고 있는 광대 역 자극음이다. 톤 버스트는 지속시간이 $200 \mathrm{msec}$ 미만인 정현 파형 음향신호로 대역폭(일반적으로 $1 / 3$ 옥타브 대역)이 제한되 어 있어 주파수별 청취 능력을 결정하는 데 사용된다. 클릭음과 톤 버스트 모두 전기생리학적 청각 역치를 추정하는 데 사용하 는데, 클릭음은 청각 선별, 병변 위치 규명, 술중 모니터링 목적 으로도 사용되는 반면 톤 버스트는 주파수 특이적 청각역치를 파악하기 위해 사용한다. 청성유발전위 시스템에서 생성된 단 기지속신호 또한 출력레벨이 측정 목적에 부합하며, 타당성 및 신뢰성이 있는지 여부를 보장하기 위해 교정이 필요하다. 즉, 모 든 종류의 청각전기생리학적 측정법에서 자극음의 교정은 자 극제시강도를 규정하고, 검사 결과의 높은 재현성을 보장하며 다른 연구자의 검사 결과와 직접 비교할 수 있게 한다. 특히 청 성유발전위의 측정 목적이 신생아 및 어린 아동의 청각역치와 같은 청각 민감도의 평가인 경우 자극음의 제시강도 또한 정상 청력과 관련하여 표시할 필요가 있다. 단기지속 자극음은 음압 파형의 특정 매개변수를 측정하여 교정되며, 이 매개변수 값은 차후 정상 청력을 가진 성인 집단에서 자극제시강도와 행동학 적 역치를 관련시키기 위해 사용된다. 예를 들어, 청성뇌간반응 (auditory brainstem response, ABR)의 V파형이 $40 \mathrm{~dB}$ 까지 기록된 경우 청성유발검사장비의 화면상에 나타난 $40 \mathrm{~dB}$ 의 출 력레벨(청성유발전위의 역치를 의미)이 일반적으로 특정한 자 극음에 대한 정상 청력인의 평균적인 행동학적 탐지역치와 비교 하여 $40 \mathrm{~dB}$ 감각수준(sensation level)이라는 사실을 알고 있 는 경우 유용하다. 그러나 행동학적 탐지역치는 단지 젊은 성인 의 $0 \mathrm{~dB}$ 이므로 정상 청력인의 유발전위(예, tone-burst $\mathrm{ABR}$ ) 또한 반드시 $0 \mathrm{~dB}$ 로 기록됨을 의미하는 것은 아니다(Katz et al., 2009). 어떤 경우, 단기지속 자극음의 교정은 청각전문가가 desired sensation level 처방법을 이용 중인 유아에게 안전히 청취할 수 있는 보청기의 증폭레벨을 결정하기 위한 목적으로 보정계수(correction factors)를 이용하여 청력도의 역치를 추 정하는 데 유용하다. 그 이유는 청력검사기에서 발생된 순음은 우선 사운드레벨미터(sound level meter)에서 dB sound pressure level (SPL) 판독 값을 이용하여 측정한 다음 정상 청력 성인의 행동학적 역치와 관련시키기 위해 $\mathrm{dB}$ hearing level $(\mathrm{HL})$ 로 표현하지만, 청성유발전위 시스템에서 발생된 단기지속 자극음의 제시강도는 일반적으로 행동학적 역치와 관련시키기 위해 $\mathrm{dB} \mathrm{nHL}$ (normal HL)로 표현하기 때문이다(Picton et al., 1976). 또 다른 예로 대뇌피질 전위(cortical potential) 측정용으 로 사용되는 지속시간이 짧은 자음-모음(consonant-vowel) 어음 자극이 큰 반응을 유발시킬 정도로 적절하게 큰 강도인지 보장하는 동시에 출력장치를 손상시키지 않고 환자에게 안전한 지 여부를 확인하는 데 유용하다.

청성유발전위에 사용되는 청력검사용 단기지속 자극음의 기 본 매개변수는 기존의 청력검사와 동일하므로 청각전문가는 출 력레벨, 주파수, 시간 등의 성능 특성을 점검해야 한다. 그러나 청성유발전위 시스템에서 발생된 단기지속 자극음을 교정할 경 우 순음 및 어음청력검사기를 교정하는 데 사용한 계측장비는 부적절하다. 그 이유는 단기지속 자극음의 경우 자극음의 지속 시간이 매우 짧으며 자극 제시시간(stimulus on-time)과 자극 중단시간(stimulus off-time)이 모두 포함되어 있으므로 순음 의 경우처럼 일정 기간 동안 소리압력의 평균 측정 값을 제공 하는 실효치(root-mean-square, RMS) 값은 단기지속 자극음 의 음압을 대표할 수 없다. 따라서 청성유발전위 시스템에서 생 성된 단기지속 자극음을 음향적인 방법뿐 아니라 전기적인 방 법으로도 검점해야 한다. 단기지속 자극음의 음향레벨을 확인 하기 위해서는 실제적인 최대 음압레벨(peak SPL, pSPL)을 직 접 기록할 수 있는 사운드레벨미터 또는 최대 음압레벨(pSPL) 또는 최대 등가음압레벨(peak-equivalent sound pressure lev$\mathrm{el}, \mathrm{peSPL}$ )을 확인하기 위해 해당 출력을 오실로스코프(oscilloscope)로 경로를 정할 수 있는 사운드레벨미터가 필요하다. 오 실로스코프는 청성유발전위 시스템의 전기적 출력을 쉽게 나 타낼 수 있지만, 이것을 분석하기 위해서는 신속하게 반복 측정 을 수행하든지 아니면 디지털 오실로스코프 또는 저장 기능을 지원해야 할 것이다. 또한 단기지속 자극음의 물리적인 레벨을 행동학적 역치와 관련시키는 것도 중요하다. 본 종설은 청성유 발전위를 측정하기 위해 주로 이용되는 단기지속 자극음(클릭 음과 톤 버스트)의 물리적인 교정 방법뿐 아니라 행동학적 교 정 방법에 대한 정보를 제공하고자 한다. 


\section{INTERNATIONAL STANDARDS RELATED TO THE CALIBRATION OF SHORT DURATION STIMULUS}

청력검사용 신호의 교정 분야에서 가장 권위 있는 표준 중 하나인 국제전기기술위원회(International Electrotechnical Commission, IEC)는 단기지속 자극음에 대한 정의 및 음압을 측정하는 방법을 표준화하여 제공(IEC 60645-3, 2007)하고 있 을 뿐 아니라 청성뇌간반응검사장비와 관련된 표준(IEC 606457, 2009)을 제공한다. IEC 60645-3(2007)에 따르면 기준 클릭 음의 전기적 파형(기준 펄스)은 상승 및 하강 시간이 $25 \mu \mathrm{s}$ 미 만이며, 지속시간이 $100 \pm 10 \mu \mathrm{s}$ (또는 $0.1 \mathrm{msec}$ )인 직사각형 전기 펄스(단상의 단일 직사각형파)이다(2-1-2 주기). 톤 버스 트라 불리는 기준 톤 버스트의 전기적 파형(기준 펄스)은 기본 정현파가 총 5 개 주기로 구성되어 각각 2 개의 주기를 차지하는 상승시간과 하강시간은 선형적이며, 최대 진폭 구간을 의미하 는 안정시간(plateau time)은 1 개의 주기이다. 단기지속 자극음 의 최대 등가음압레벨(dB peSPL)을 측정하기 위해 피크 간 등 가음압레벨(peak-to-peak equivalent sound pressure level, $\mathrm{dB}$ p-p.e.SPL)을 사용하도록 규정하고 있다.

국제표준화기구(International Standardization Organization, ISO)에서는 클릭음 및 중심 주파수가 고정되어 있는 기준 (2-1-2 주기) 톤 버스트의 교정 값으로 피크 간 등가기준등가역 치음압레벨(peak-to-peak equivalent reference equivalent threshold sound pressure levels, peRETSPLs), 즉 $\mathrm{dB} \mathrm{p}-\mathrm{p}$. e.SPL 단위로 표현된 기준등가역치음압레벨(reference equivalent threshold sound pressure levels, RETSPLs)을 제공한다 (ISO 389-6:2007). 상기 표준은 일반적으로 사용되고 있는 다 양한 종류의 이어폰(귀덮개형, 귀걸이형, 삽입형 이어폰) 및 커 플러에서 클릭음 및 톤 버스트의 peRETSPLs를 규정하고 있 으며, 음장(free-field condition)에서 사용할 수 있는 클릭음의 peRETSPL도 명시되어 있다. 또한 Radioear B-71 bone vibrator (Radioear, New Eagle, PA, USA)에서 클릭음의 피크 간 등가기준등가역치진동력레벨(peak-to-peak equivalent reference equivalent threshold vibratory force levels, peRETVFLs)도 제공한다. peRETSPLs와 peRETVFLs는 특정 출력장 치에 대한 적절한 커플러에서 청각역치를 표현한 것으로 각각 특정 주파수에서 18 25세 사이의 남녀 모두를 포함하는 충분 히 많은 수의 이과학적으로 정상인 사람의 등가역치음압레벨 및 등가역치진동력레벨의 중앙값을 기준으로 한다. ISO 3896(2007)은 제한된 수의 이어폰(한 개의 골진동기, 한 개의 스피 커)에 대한 교정 값만 제공한다. 귀걸이형 이어폰 및 귀덮개형 이어폰의 교정 값은 IEC 60318-1(2009)에 명시된 귀 모의장치 (ear simulator)만 사용 가능하며, 삽입형 이어폰의 교정 값은 IEC 60318-4(2010)에 규정된 폐쇄형 귀 모의장치(occludedear simulator)인 711-coupler에 대해서만 제공된다. 그러나 삽 입형 이어폰의 경우 Haughton(2006)은 IEC 60318-5(2006)에 명 시된 2 cc coupler에서 ER-3A insert earphone (Etymotic Research, Inc., Elk Grove Village, IL, USA)에 사용할 수 있는 변 환 수치를 제공한다. 상기 언급한 peRETSPLs는 몇 가지 서로 다른 자극제시속도(stimulus presentation rate)에서 구한 역치 를 기반으로 하였으며, IEC 60318-5(2006)는 표준 자극제시속 도인 $20 \mathrm{~Hz}(\mathrm{stim} / \mathrm{s})$ 에서 구한 역치를 정규화하기 위해 사용되 는 보정 값을 기술하고 있다. 따라서 상기 두 국제표준을 참고 하는 경우 특정 클리닉 또는 실험실에서 다른 클리닉 또는 실 험실의 검사 결과를 직접 비교할 수 있다.

\section{DIFFERENCES OF CALIBRATION BETWEEN LONG DURATION SIGNAL AND SHORT DURATION SIGNAL}

순음청력검사에 사용하는 다양한 주파수의 순음 자극은 일 반적으로 수 초 동안 제시되며 사운드레벨미터를 사용하여 출 력레벨을 점검할 수 있는 특정한 기준등가역치레벨(reference equivalent threshold level)을 가지고 있다. 순음의 기준등가역 치음압레벨(RETSPLs) 및 기준등가역치진동력레벨(reference equivalent threshold vibratory force levels, RETVFLs)은 이 과적으로 정상인 젊은 성인의 평균 청각역치를 반영한다. 대부 분의 사운드레벨미터는 반응통합시간을 의미하는 두 종류의 지 수적 시간가중평균방식(exponential time-weighted averaging modes), 즉 고속(fast) 또는 저속(slow) 모드를 기본으로 지원 하므로 순음의 기준등가역치레벨(예, RETSPLs 및 RETVFLs) 은 일정 기간 동안의 소리압력의 평균 값을 의미하는 음압파형 의 실효치(RMS) 값을 측정하는 사운드레벨미터의 지수적 시 간가중함수를 기반으로 한다. 고속 및 저속 지수적 시간가중평 균방식의 시간상수(time constants)는 각각 0.125 초(125 msec) 와 1초 $(1,000 \mathrm{msec})$ 로 고속 설정은 $125 \mathrm{msec}$ 이상의 신호를 평 균화하는 반면 저속 설정은 $1,000 \mathrm{msec}$ 이상의 신호의 평균 값(RMS 값)을 측정한다(Yeager \& Marsh, 1991). 그러나 두 경 우 모두 이전에 발생한 소리가 지수적 시간가중함수에 미치는 영향을 무시할 수 있기까지는 약 4배의 시간상수가 필요하다. 즉, 어떤 소리의 지속시간이 특정 시간상수의 4 배보다 짧은 경 우(고속 지수적 시간가중함수의 경우 0.5 초, 저속 지수적 시간 가중함수의 경우 4초), 사운드레벨미터에서 측정된 음압레벨 (예, RMS 값)은 실제 제시된 소리의 음압레벨(SPL)보다 과소평 가된다. 청성뇌간반응과 같은 대부분의 청성유발전위는 개시반 
응(onset responses)으로 일반적으로 단기지속 자극음으로 유 발되며, 해당 자극의 제시 동안 첫 수 $\mathrm{msec}$ 에서 유발되기 때문 에 주로 자극음의 상승시간에 영향을 받는다(Davis et al., 1984). 이러한 AEPs는 일반적으로 지속시간이 $0.1 \mathrm{msec}$ 에서 수 $\mathrm{msec}$ 정도인 클릭음 또는 톤 버스트의 초기 개시 시점에만 반 응한다. 단기지속 자극음(클릭음 또는 톤 버스트)의 지속시간 은 고속 지수적 시간가중평균방식의 시간상수와 비교해도 훨 씬 짧기 때문에 음압 측정기의 지수적 시간가중평균 방식을 이 용할 경우 고속 및 저속 지수적 시간가중평균방식 모두 음압을 적절하게 통합하지 못하며 실제 단기지속 자극음의 음압은 궁 극적으로 과소평가된다. 또한 사운드레벨미터의 전자적 측정 시스템에서 일정 기간 동안의 소리압력의 평균 측정 값을 제공 하는 RMS 값은 자극 제시시간과 자극 중단시간을 모두 포함 하므로 파형이 안정 상태(steady state)가 아닌 단기지속 자극음 의 음압을 대표하지 못한다(Burkard, 1984).

\section{TEMPORAL INTEGRATION}

매우 낮은 자극제시속도( $\leq$ 약 $2 \mathrm{~Hz}$ )에서 $200 \mathrm{msec}$ 의 임계 지속시간(critical duration)보다 짧게 제시되는 자극음의 경우 정상 청력인 귀의 행동학적 탐지역치는 자극음의 지속시간이 감소함에 따라 증가한다. 즉 행동학적 탐지역치는 자극음의 지 속시간에 따라 변화하는데, 지속시간이 최대 약 $200 \mathrm{msec}$ 가 될 때까지 자극음의 지속시간이 두 배로 증가할 때마다 $-3 \mathrm{~dB}$ 로 변화한다. 이러한 현상은 시간적 통합(temporal integration) 때 문에 발생하며(Hirsh, 1975), 단기지속자극의 행동학적 탐지역 치는 자극 개시(stimulus onset) 후 $200 \mathrm{msec}$ 내에서 측정된 음 압의 RMS 값에 따라 변한다(Pedersen \& Elberling, 1972).

또한 자극제시속도가 증가함에 따라 빠르게 제시되는 자극 의 시간적 통합의 결과로 인해 단기지속 자극음은 사람의 귀에 더 큰소리로 지각될 수 있다. 자극제시속도(및 자극제시레벨)를 증가시키는 경우 해당 자극에 대한 행동학적 탐지역치는 향상 되지만 청성뇌간반응의 경우 이러한 에너지를 행동학적 탐지역 치와 동일한 방식으로 통합하지는 않는다. 실제로 청성뇌간반 응에서 자극 속도를 증가시킬 경우 파형의 형태가 저하된다. 그 이유는 자극제시속도가 5 10 Hz보다 빠른 경우 $200 \mathrm{msec}$ 의 통합시간(integration time)이 완료되기 전에 다음 자극이 제시 되기 때문에 시간적 통합은 단지 부분적으로만 발생하기 때문 이다. 예를 들어, 자극제시속도가 $40 \mathrm{~Hz}$ 와 $70 \mathrm{~Hz}$ 인 경우 해당 자극음은 각각 $25 \mathrm{msec}$ 와 $14.3 \mathrm{msec}$ 마다 제시된다. 전기생리 학 분야에서 상기 언급한 단기지속 자극음(클릭음, 톤 버스트, chirps, octave-band chirps)는 일반적으로 $10 \mathrm{~Hz}$ 에서 $100 \mathrm{~Hz}$ 범위의 속도로 제시된다. 이러한 자극제시속도에서 시간적 통합
은 부분적으로 발생하므로 행동학적 역치는 자극제시속도 및 지속시간에 따라 복잡한 방식으로 변화한다. 따라서 RETSPLs 의 탐지역치 또한 자극음의 지속시간 및 자극제시속도에 의존할 것이다. 결론적으로 단기지속 자극음을 사용할 경우 이러한 종류 의 자극음의 평균 청각역치를 정확하게 반영하는 RETSPLs를 가져야 한다.

\section{CONSIDERATIONS RELATED TO THE RATE OF STIMULUS PRESENTATION}

앞서 설명한 바와 같이 단기지속 자극음으로 유발된 청성뇌 간반응과 같은 초기 청성유발전위의 경우 자극제시속도에 따라 반응이 다르게 나타난다. 또한 단기지속 자극음의 행동학적 탐 지역치도 자극제시속도에 따라 다르게 나타난다(Beattie \& Rochverger, 2001; Yost \& Klein, 1979). 따라서 ISO 3896(2007)의 교정 값은 초당 20회의 자극제시속도에서만 유효하 다. 이 자극제시속도는 기준청각역치레벨을 결정하기 위해 선호 되는 검사 조건 중 한 가지로, 보다 최근 표준인(ISO 389-9: 2009)에서 권장한다. ISO 389-6(2007)에서는 두 종류의 이어폰 [HDA 200 (Sennheiser electronic GmbH \& Co., Old Lyme, CT, USA); TDH-39 (Telephonics Corporation, Farmingdale, NY, USA)]에서 10 100 Hz 범위의 자극제시속도에 따라 클릭 음의 행동학적 역치가 어떻게 변화되는지에 대한 정보를 제공 한다. 클릭음의 자극제시속도를 대수 축상에 기입한 경우 $\mathrm{dB}$ p-p.e.SPL로 표현한 행동학적 역치의 변화는 거의 선형적으로 자극제시속도가 두 배로 증가될 때마다 역치가 약 $1.85 \mathrm{~dB}$ 감소 된다. 그러나 대역폭을 제한시킨 톤 버스트의 경우 동일한 두 종 류의 출력장치(Sennheiser HDA 200과 Telephonies TDH-39) 에서 평균 값이 $2.1 \mathrm{~dB}$ 로 약간 더 높게 나타났으며, 고주파수 자극보다는 저주파수 자극이 자극제시속도에 영향을 더 많이 받는 경향을 보였다(Fedtke \& Richter, 2007). 자극제시속도에 따른 행동학적 역치의 변화는 자극제시속도가 두 배로 증가할 때마다 약 $-2 \mathrm{~dB}$ p-p.e.SPL 규칙으로 변화된다. 예를 들어, 자 극제시속도가 $20 \mathrm{~Hz}$ 에서 $100 \mathrm{~Hz}$ 로 변화되는 경우 약 $-4.5 \mathrm{~dB}$ p-p.e.SPL이다. ISO 389-6(2007)은 속도 정보가 임상적 맥락 에서 어떻게 다루어져야 하는지에 대한 권장 사항이나 지침은 제공하지 않는다. 그러나 Lightfoot et al.(2007)은 국제 유발반응 청력검사 연구회(International Evoked Response Audiometry Study Group)를 대표하여 자극제시속도에 관한 문제를 언급하 였는데, 단기지속 자극음은 개별적인 임상검사에서 적용되는 실제 자극제시속도에 관계없이 ISO 389-6(2007)에 명시된 표 준화된 기준 값, 즉 $20 \mathrm{~Hz}$ 를 이용하여 교정해야 한다고 주장하 였다. 


\section{CALIBRATION OF SHORT DURATION STIMULUS}

청성유발전위는 단기지속 자극음의 최대 레벨(peak-related sound level)에 의해 좌우된다. 반면 단기지속 자극음의 행동학 적 역치는 소리의 RMS 값(RMS-related sound level) 또는 고 막에 제시된 시간평균 소리 에너지와 비교적 밀접하게 관련되 어 있다. 따라서 청각전문가는 청성유발전위 시스템의 자극음 교정을 위해 행동학적 교정(behavioral calibration)[또는 심리 음향적 교정(psycho-acoustical calibration)]과 물리적 교정 (physical calibration)[또는 음향물리적 교정(acoustico-physical calibration)] 절차를 모두 이용할 수 있다. 행동학적 교정은 정상 청력인에서 특정 자극음의 물리적인 자극제시레벨을 행 동학적 역치와 관련시키는 방법으로 일과성 자극음(acoustic transients)의 교정에 주로 사용된다(Stapells et al., 1982). 이 교정방법은 단기지속 자극음의 평균 음압(RMS 값)에 의존적 이다. 앞서 설명한 바와 같이 IEC 60645-3(2007)은 단기지속 자극음의 물리적 레벨로 $\mathrm{dB}$ p-p.e.SPL 단위를 사용하도록 권 장하며, ISO 389-6(2009) 역시 dB p-p.e.SPL 단위의 RETSPL 값을 제공한다. 일정한 물리적 자극레벨(dB p-p.e.SPL 단위)에 서 청성뇌간반응의 진폭은 적응과 같은 신경 기전으로 인해 자 극제시속도가 증가함에 따라 감소하며(Burkard et al., 2007), 단기지속 자극음의 행동학적 역치와 비례하는 $\mathrm{dB} \mathrm{nHL}$ 단위의 레벨은 자극제시속도가 $20 \mathrm{~Hz}$ 에서 $100 \mathrm{~Hz}$ 로 증가함에 따라 약 $4.5 \mathrm{~dB}$ 증가한다. 따라서 $\mathrm{dB} \mathrm{nHL}$ 의 자극레벨의 증가에 대 한 반응으로 $\mathrm{ABR}$ 진폭의 감소가 관찰된다. 행동학적 역치는 청력검사상 정상 청력을 가진 개인 집단(최소 5 명에서 최대 20 30명으로 가능한 동종 집단으로 구성)을 대상으로 청성유 발전위 시스템에서 지원하는 모든 종류의 자극음과 관련 출력 장치에 따라 개별적으로 결정한다. 이 경우 검사 대상자 수가 많을수록 행동학적 역치의 정확도(precision)는 더욱 향상된다. Richter \& Fedtke(2005)는 행동학적 교정을 위해 자극음의 극 성을 교대상(alternating polarity)으로 사용할 것을 제안하였 지만, Stapells et al.(1982)은 TDH-49 (Telephonics Corporation) 헤드폰을 사용하는 경우 희박상(rarefaction) 및 압축상 (condensation) 클릭음 간의 차이가 없음을 발견하였다. 자극 제시속도는 일반적으로 $10 \mathrm{~Hz}$ 또는 $20 \mathrm{~Hz}$ 가 사용되지만, 병원 의 프로토콜을 기반으로 다른 자극 속도를 사용할 수도 있다. 행동학적 교정은 가능하다면 음향적으로 차폐된 방음실에서 시행해야 하며, 역치는 협차법(bracketing procedure)을 이용 하여 결정한다. 특정 자극음의 평균역치(중앙 값을 의미)는 컴 퓨터 화면 또는 강도조절 다이얼 위에 표시된 강도레벨에 관계 없이 $0 \mathrm{dBnHL}$ 이 될 것이다. 즉, $0 \mathrm{~dB} \mathrm{nHL}$ 은 청성유발전위 시
스템에서 항상 $0 \mathrm{~dB}$ 이 아닐 가능성이 존재하므로 청성유발전 위 시스템 화면에 표시된 $10 \mathrm{~dB}$ 의 강도레벨이 $0 \mathrm{~dB} \mathrm{nHL}$ 과 동 일한 경우 청각전문가는 모든 검사음 제시레벨에서 $10 \mathrm{~dB}$ 을 차 감해야 한다. 또한 청각전문가는 유발전위 시스템 화면에 표시 된 $0 \mathrm{~dB}$ 의 강도레벨이 실제 $0 \mathrm{~dB} \mathrm{nHL}$ 과 동일하게 만들기 위해 프로그램에서 내부적으로 보정하는 기능을 사용할 수도 있다. 그러나 청각전문가는 단지 행동학적 교정에만 의존하지 않아야 하며(Jacobson, 1994; Lightfoot et al., 2007), 아래에 제시한 필 수 교정장비를 이용할 수 없는 경우에 한해 제한적으로 이용해 야 한다.

청성유발전위는 단기지속 자극음의 최대 음압에 영향을 받 기 때문에 단기지속 자극음의 물리적 레벨은 peSPL 또는 p-p. e.SPL로 규정되었다. 따라서 단기지속 자극음의 물리적 교정은 일반적으로 peSPL 또는 p-p.e.SPL로 측정한다. 물리적 교정 값은 또한 청성유발전위 시스템의 컴퓨터 화면 또는 강도 다이 얼에 표시된 강도레벨과 관련이 있어야 하므로 다양한 종류의 출력장치를 통해 제시되는 다양한 자극음의 출력레벨 또는 기 준등가역치음압강도를 점검하기 위해 특수한 교정용 장비와 절 차를 이용해야 한다(Richter \& Fedtke, 2005). 물리적 교정에 필요한 최소 장비에는 청성유발전위 시스템과 출력장치, 적절 한 커플러, 사운드레벨미터, 신호 발생장치(또는 기준음 생성장 치), 오실로스코프가 포함된다. 물리적 교정을 수행할 경우 자 극음은 적절하게 높은 레벨에서 제시하여 사운드레벨미터의 판독 값에서 자극제시레벨을 차감해야 한다. 적절하게 높은 강 도의 자극음을 사용하는 이유는 실내 주변소음이 사운드레벨 미터의 판독 값에 영향을 미치지 않게 하기 위함이다. 임상적인 교정절차의 경우 $6 \mathrm{cc}$ 또는 $2 \mathrm{cc}$ 커플러(coupler)에 연결시킬 수 있는 이어폰을 사용하는 것이 바람직하다. MX 41/AR 또는 Telephonics type 51 귀 완충물(ear cushions)을 장착한 TDH39s, TDH-49s, TDH-50s (Telephonics Corporation)와 같은 귀 걸이형 이어폰은 6 cc (NBS 9-A) coupler, Etymotic ER-1, ER-2, ER-3A (Etymotic Research, Inc.)와 같은 삽입형 이어 폰은 $2 \mathrm{cc}$ coupler로 연결시킬 수 있다. 일반적으로 상기 두 종 류의 커플러( $2 \mathrm{cc}$ 또는 $6 \mathrm{cc}$ coupler)의 기저부에는 1" 콘덴서 압 력 마이크로폰(condenser pressure microphone)을 장착시킬 수 있도록 설계된 공간이 있지만, 일부 커플러의 경우 $1 / 2$ " 마이크 로폰을 장착할 수 있도록 설계되어 있다. 마이크로폰의 출력은 사운드레벨미터 또는 콘덴서 마이크로폰에 분극전압(polarization voltage)을 제공하는 증폭기로 경로를 지정할 수 있다. 교정을 완료한 청력검사기는 신호 발생기로 사용할 수 있다. 데 스크톱 컴퓨터 또는 노트북에 고음질의 사운드카드가 장착된 경우 오실로스코프를 사용하는 방법이 비용대비 효율적이며 데스크톱 오실로스코프와 유사한 결과를 얻을 수 있는 실용적 
인 대안이다.

사운드레벨미터를 이용하여 단기지속 자극음의 음압레벨 (SPL)을 측정하는 경우 음압레벨 측정에 사용되는 시간상수에 따라 복잡하다. 일반적으로 청력검사역치(audiometric thresholds)는 사운드레벨미터의 고속 또는 저속 지수적 시간가중평 균방식을 이용하여 음압레벨을 정확하게 측정할 수 있도록 충 분한 지속시간 동안 재생되는 자극의 역치를 의미한다. 지수적 시간가중평균방식(예, “고속” 또는 “저속” 모드) 중 한 가지를 사용하는 경우 해당 방식의 시간상수보다 지속시간이 훨씬 짧 은 신호의 안정 상태의 음압레벨은 매우 과소평가된다. 청성유 발전위를 측정하는 경우 단기지속 음향자극이 주로 사용되므 로 이러한 유형의 자극음의 음압레벨을 결정하는 또 다른 방법 이 필요하다. 시간가중평균방식의 음압레벨 측정법에서 발생하 는 문제를 해결할 수 있는 방법은 여러 가지가 존재한다. 그중 한 가지 방법은 톤 버스트를 수 초 동안 재생시킬 수 있는 경우 사운드레벨미터의 고속 및 저속 지수적 시간가중평균방식으로 톤 버스트의 레벨을 기록할 수 있다. Katz et al.(2009)은 톤 버 스트의 지속시간을 일시적으로 몇 초 정도로 연장시켜 안정 상 태의 음으로 만든 경우 실제 음압레벨과 거의 유사하다고 주장 하였다. 따라서 만약 4 배 이상의 시간상수(고속 모드의 경우 500 $\mathrm{msec}$, 저속 모드의 경우 $4,000 \mathrm{msec}$ )에서 측정하는 경우, 측정 된 수치는 해당 자극음의 실제 지수적 시간가중평균 음압레벨 과 거의 비슷할 것이다. 이것은 일반적으로 톤 버스트의 peSPL 이라 언급되고 있는 것을 구할 수 있는 방법 중 하나이다. 그러 나 클릭음의 경우 전기 펄스의 지속시간을 증가시키면 자극의 스펙트럼이 변화되기 때문에 이러한 방법은 클릭음에는 적용할 수 없다.

앞서 설명한 것처럼 단기지속 자극음의 교정에 참고할 수 있 는 두 가지 국제표준이 존재한다(IEC 60645-3, 2007; ISO 389-6, 2007). 두 국제표준 모두 단기지속 자극음의 레벨을 p-p.e.SPL로 정량화한다. 즉, 출력장치에서 생성된 단기지속 자극음 $(100 \mu \mathrm{sec}$ click, tone burst)의 피크 간 파형을 동일한 출력장치에서 생성시킨 이미 알고 있는 참조 신호(reference sig$\mathrm{nal}$ [예, $1,000-\mathrm{Hz}$ 또는 동일 주파수의 정현파]의 피크 간 파형 과 유사한 것을 찾아낸다. 측정은 교류 출력(alternating current output)을 오실로스코프로 전송시킬 수 있는 교정된 사운 드레벨미터를 통해 수행한다. 불행히도 단기지속 자극음의 교 정은 국제표준에서 설명하고 있는 것보다 조금 더 복잡하다. 예 를 들어, 서로 다른 종류의 출력장치에서 생성된 단기지속 자 극음의 시간적 파형(temporal waveform)은 종종 오실로스코 프의 기준선인 영점(zero baseline)에 대해 동일하지 않을 것이 다. 이로 인해 p-p.e.SPL 방법에 기반한 기준등가역치음압강도 는 적절하지 않을 수도 있다. 따라서 일부 전문가들은 이들 국
제표준조차 여전히 부족하다는 사실을 발견하였다(Lightfoot et al., 2007). Robert Burkard가 주도하고 있는 미국표준협회 (American National Standards Institute, ANSI) S.3 Bioacoustics 실무그룹(working group)이 ANSI 표준 초안에 추가적인 측정을 제안하고 있는 것은 이러한 이유 때문이다. ANSI 표준 초안에서 단기지속 자극음의 레벨을 정량화하기 위해 $\mathrm{pSPL}$, 기 준선 대 피크 등가음압레벨(baseline-to-peak equivalent SPL, b-p.e.SPL), p-p.e.SPL 등의 측정법을 추가적으로 포함하고 있 다. 어떠한 접근방식을 사용하는지에 따라 최대 $6 \mathrm{~dB}$ 까지 차이 가 날 수 있다는 사실을 명심해야 한다(Burkard, 1984; Katz, 2002). 단기지속 음향자극의 레벨을 측정하는 수많은 방법이 있 지만, 문헌에 사용된 가장 일반적은 측정법은 pSPL 및 peSPL 추정치이므로 본 종설에서는 이러한 각각의 측정법에 대해 살 펴볼 것이다.

\section{THE MEASUREMENT OF PEAK AND PEAK EQUIVALENT SOUND PRESSURE LEVEL}

\section{최대 음압레벨(Peak sound pressure level)}

적절한 커플러 및 마이크로폰과 함께 사운드레벨미터만 구비 하고 있으면 pSPL을 결정할 수 있다. 유형 1 사운드레벨미터는 고속 및 저속 지수적 시간가중평균방식으로 음압레벨을 기록 할 수 있으며, 대부분의 경우 충격(impulse) 시간가중 측정 및 최댓값(peak) 측정을 포함한 그 외 다른 종류의 시간가중 측정 법으로도 음압레벨을 측정할 수 있다. 충격 시간가중 측정은 다양한 산업현장에서 발생되는 충격음(impulsive sounds)을 측정하기 위해 고안되었으며, $35 \mathrm{msec}$ 의 생성 통합시간(onset integration time)과 수백 msec의 종료 통합시간(offset integration time)을 가지고 있다. 따라서 충격 시간가중방식은 청성 유발전위를 유발시키는 데 일반적으로 사용되는 단기지속 자극 음의 소리 측정 방식으로 적절하지 않다. 또한 청성유발전위에 사용되는 단기지속 음향신호의 경우 지속시간이 지수적 시간가 중평균방식에 규정되어 있는 다양한 시간상수보다 짧아 사운드 레벨미터에서 측정된 음압레벨은 자극음의 실제 음압레벨을 과 소평가하게 될 것이므로 고속 및 저속 지수적 시간가중평균방식 으로 음압레벨(RMS 값)을 측정하는 것은 적절하지 않다.

단기지속 자극음은 파형이 안정 상태가 아니므로 사운드레벨 미터를 이용하여 음압레벨을 확인하기 위해서는 순간최대 음압 레벨(instantaneous pSPL)을 측정할 수 있으며, 재설정될 때까 지 표시화면에 이 최대 압력 값을 “유지(hold)"시키는 기능을 지 원해야 한다. pSPL을 측정하는 공식은 $\mathrm{pSPL}=20 \log$ (Pmax/ Pref)이며, 여기서 Pmax는 $\mathrm{Pa}$ (pascal) 단위의 순간최대압력 
(instantaneous peak pressure)이며, Pref는 기준음압인 $20 \mu$ $\mathrm{Pa}$ 에 해당한다. 그러나 사운드레벨미터에서 측정된 최대 음압 이 이어폰으로 전송된 특정 자극에서 발생하였는지 아니면 원 치 않는 음원에서 생성된 큰 저주파수 압력에서 발생하였는지 여부를 결정할 수 없다는 사실에 유의해야 한다. 기록된 pSPL 이 의도하지 않게 제시된 자극 때문이 아니라 측정 대상인 특 정 자극음의 최대 음압이 되도록 주의를 기울여야 한다. 또한 최대 음압측정모드(peak-hold mode)의 경우 사운드레벨미터 의 유형에 따라 이러한 “최댓값(peak)”이 평가되는 측정 시간간 격(시간상수)이 다르기 때문에 특정 사운드레벨미터에 따라 다 른 값을 나타낼 수 있다. pSPL의 측정을 지원하는 사운드레벨 미터는 특정 측정 시간간격 $(50 \mathrm{msec}$ 이하의 통합시간)에서 순간 적으로 가장 큰 음압레벨을 이용하여 음압레벨을 계산한다. 즉, 최대 압력을 정확하게 추정하기 위해 표본화 기간(sampling period)은 단기지속 자극음의 지속시간보다는 실질적으로 짧 아야 하므로 수십 $\mu \mathrm{s}$ 이하의 시간상수를 지원하는 사운드레벨 미터를 사용하는 것이 바람직하며, 고속 모드로 설정해야 한다. 지수적 시간가중평균방식의 경우 RMS 값을 이용하므로 음압 레벨의 평균을 반영하며, pSPL은 특정 시간간격에서 순간적으 로 가장 큰 음압(순간최대 음압)을 기반으로 한다.

물론, pSPL을 결정하기 위해 반드시 사운드레벨미터를 사용 해야 할 필요는 없다. 사운드레벨미터를 사용하지 않고 커플러, 마이크로폰, 마이크로폰 조정증폭기(microphone conditioning amplifier), 디지털 오실로스코프를 이용하여 단기지속 자극음 의 pSPL을 측정할 수 있다. 이 방법에서는 적절한 커플러와 마 이크로폰을 마이크로폰 조정증폭기에 연결하고, 조정증폭기는 오실로스코프에 연결한 후 단기지속 자극음을 제시하여 오실로 스코프에서 최대전압을 측정한다. 마이크로폰 출력전압을 입력 음압 및 음압레벨로 변환[전압-압력 변환(voltage-to-pressure conversion)]하기 위해서는 음압을 이미 알고 있는 음원[예, 음향 교정기 또는 표준음 발생기(acoustic calibrator/pistonphone)]을 이용하여 마이크로폰을 교정하거나 또는 마이크로폰 진동판에 서의 압력을 출력전압과 관련시킨 마이크로폰 감도 곡선을 사 용할 수 있다.

음향 교정기를 이용하는 경우 마이크로폰에 연결시키고 마이 크로폰 조정증폭기의 출력전압을 측정한다. 이 방식에서 마이 크로폰 진동판에 특정 음압레벨이 제시될 경우 그에 부합하는 특정 전압이 생성된다. 예를 들어, $114 \mathrm{~dB}$ SPL을 출력하는 음 향 교정기를 보유하고 있으며, 적절한 커플러에 $1 \mathrm{mV} / \mathrm{Pa}$ (millivolts/pascal)의 감도를 가진 마이크로폰 및 100배 이득(gain) 의 증폭기를 배치한 경우 마이크로폰 조정증폭기의 출력전압은 $1 \mathrm{~V}(\mathrm{RMS})$ 로 측정될 것이다. 여기서 $114 \mathrm{~dB}$ SPL은 $10 \mathrm{~Pa}(114$ $\mathrm{dB} \mathrm{SPL}=20 \log (10 \mathrm{~Pa} / 0.00002 \mathrm{~Pa})$ 에 해당한다. 따라서 $1 \mathrm{mV} /$
$\mathrm{Pa} \times 100$ (gain) $=100 \mathrm{mV}$ 이며, $114 \mathrm{~dB} \mathrm{SPL}=10 \mathrm{~Pa}$ 이므로 100 $\mathrm{mV} \times 10=1,000 \mathrm{mV}$ (또는 $1 \mathrm{~V}$ )가 될 것이다. 실제 교정 절차는 Etymotic ER-3A 삽입형 이어폰을 $2 \mathrm{cc}$ 커플러(마이크로폰 포 함)에 연결한 후 단기지속 자극음을 제시한다. 이후 최대 음압레 벨을 측정하기 위해 오실로스코프에서 초기 양성전압과 그 이 후에 음성전압을 가진 단기지속 자극음의 최대전압을 측정한다. 이 경우 음압레벨을 구하기 위해 최대전압을 선택하여 아래 공 식에 대입한다. 만약 최대 전압이 $50 \mathrm{mV}$ 로 측정되었다면 아래 의 Eq. [1]을 이용하여 구할 수 있다.

$\mathrm{dB} \mathrm{SPL}=20 \log (50 \mathrm{mV} / 1,000 \mathrm{mV})+114 \mathrm{~dB} \mathrm{SPL}=88 \mathrm{~dB}$ pSPL Eq. [1]

Eq. [1]의 첫 번째 부분은 $\mathrm{dB}$ re: $114 \mathrm{~dB}$ SPL을 추정하였는 데, 이 값은 $-26 \mathrm{~dB}$ 이다. 즉 " $\mathrm{dB}$ re: $114 \mathrm{~dB}$ SPL"을 "dB SPL" 로 변환하기 위해 114 를 추가하였다.

마이크로폰이 압력을 전압으로 변환할 때 이 두 측정 값 간 에는 선형적인 관계가 존재하며, 이는 일반적으로 $\mathrm{mV} / \mathrm{Pa}$ 로 표 현되는 마이크로폰의 감도(microphone sensitivity)로 설명된 다. $1 \mathrm{mV} / \mathrm{Pa}$ 은 마이크로폰 진동판에 $1 \mathrm{~Pa}$ 의 음압을 제시하는 경우 마이크로폰은 $1 \mathrm{mV}$ 의 전압을 출력함을 의미하므로 압력 과 전압을 상호 교환하여 사용할 수 있다. $1 \mathrm{~Pa}$ 은 $94 \mathrm{~dB} \mathrm{SPL} \mathrm{(dB}$ $\mathrm{SPL}=20 \log \mathrm{P} / 0.00002 \mathrm{~Pa}$ )이므로, 이것을 증폭기에서 100배 $(40 \mathrm{~dB})$ 정도 증폭하는 경우 $100 \mathrm{mV} / \mathrm{Pa}$ 을 생산해야 한다. 이 렇게 증폭된 전압은 오실로스코프 또는 전압계에서 정확하게 판독할 수 있다. 마이크로폰의 감도 곡선을 이용하여 마이크로 폰 출력전압과 압력의 관계를 파악하게 되면 오실로스코프에 서 관찰된 특정 단기지속 자극음의 순간최대전압은 Pascals 단 위의 최대압력(peak pressure, Pmax)으로 변환시킬 수 있다. 이 최대압력은 앞서 설명한 것처럼 다음의 Eq. [2]를 이용하여 pSPL로 변환된다.

$$
\text { pSPL }=10 \log \left(\operatorname{Pmax}^{2} / \text { Pref }^{2}\right)=20 \log (\operatorname{Pmax} / 20 \mu \mathrm{Pa})
$$

Eq. [2]

예를 들어, 최대전압이 $100 \mathrm{mV}$ 로 측정되었고 마이크로폰 감 도가 $50 \mathrm{mV} / \mathrm{Pa}$ 인 경우 $50 \mathrm{mV}$ 의 출력전압은 $1 \mathrm{~Pa}$ 의 입력음압 을 나타내므로, $100 \mathrm{mV}$ 의 출력전압은 $2 \mathrm{~Pa}$ 의 입력음압을 의미 한다. 이 예제에서 $\mathrm{pSPL}$ 로 변환하는 방법은

pSPL $=20 \log (2 \mathrm{~Pa} / 0.00002 \mathrm{~Pa})=20 \log 10,000$

$=\sim 100 \mathrm{~dB} \mathrm{pSPL}$ 
이 값은 사운드레벨미터의 최대 음압측정모드에서 산출된 $\mathrm{pSPL}$ 과 동일해야 하지만, 시간상수가 너무 긴 경우(예, $100 \mu \mathrm{s}$ ) 더 낮은 값을 산출할 수도 있다. 특정 자극음의 경우 $\mathrm{b}-\mathrm{p}$. e.SPL은 실제 pSPL 값보다 $3.01 \mathrm{~dB}$ 작아야 한다. 그렇다면 특 정 신호의 지수적 시간가중음압레벨과 pSPL 사이의 관계는 무엇인가? 이것은 파고율(crest factor)에 반영되므로 특정 신호 에 따라 달라진다. 파고율(peak-to-RMS ratio, peak value/ RMS value)은 최대 압력(또는 전압)과 RMS 압력(또는 전압) 사이의 관계를 반영한다. 즉 peSPL을 측정할 경우 정현파의 지 수적 시간가중평균 소리레벨은 단기지속 자극음의 최댓값 또 는 피크 간(peak-to-peak) 값과 관련시키기 때문에 정현파의 파고율을 알고 있는 경우 유용하게 사용할 수 있다. 실제 정현 파의 파고율은 1.414 로 밝혀졌고, 대수 단위로 $20 \log (1.414)$, 즉 약 $3 \mathrm{~dB}$ 이다. 정현파의 경우 $\mathrm{pSPL}$ 은 지수적 시간가중평균 소 리레벨보다 $3 \mathrm{~dB}$ 더 크다.

\section{최대 등가음압레벨(Peak equivalent sound pressure level)}

시간가중평균방식의 음압레벨 측정법에서 발생하는 문제를 해결하고 클릭음을 포함한 모든 종류의 단기지속 자극음의 측 정법에 대한 ISO 및 IEC 표준을 준수하는 한 가지 방법은 교 류 출력단자를 지원하는 사운드레벨미터와 오실로스코프를 사 용하여 peSPL을 측정하는 것이다. 이 표준에 따르면 피크 간 등 가 신호레벨(peak-to-peak equivalent signal level)은 "동일한 검사 조건하에서 검사 중인 출력장치에서 생성된 단기지속신호 의 출력과 비교할 때 단기지속신호와 동일한 피크 간 진폭을 갖 는 장기지속 정현파 신호의 RMS 값“으로 정의하고 있다. 이 방 법은 최대 진폭에 관한 측면에서 자극음의 출력을 연속음의 출 력과 일치시키는 것으로 표면상으로는 최대 진폭을 측정하는 것이지만, RMS 진폭을 사운드레벨미터에서 쉽게 측정할 수 있 는 안정 상태의 음과 동일시하려는 의도이다. 따라서 이 방법은 교류 출력단자를 지원하는 사운드레벨미터와 오실로스코프가 필요한데, 특히 사운드레벨미터는 정류 또는 시간가중 전 단계 에서 마이크로폰의 출력전압을 정확하게 재현할 수 있어야 한 다. 이 경우 마이크로폰의 교류 출력전압은 오실로스코프로 연 결할 수 있다. 사운드레벨미터의 출력에서 기준선 대 피크 (baseline-to-peak, b-p) 또는 피크 간(peak-to-peak, p-p) 전 압이 단기지속 자극음의 $\mathrm{b}-\mathrm{p}$ 또는 $\mathrm{p}-\mathrm{p}$ 전압과 동일한 경우 peSPL은 사운드레벨미터의 교류 출력전압에서 단기지속 자극 음의 $\mathrm{b}-\mathrm{p}$ 또는 $\mathrm{p}-\mathrm{p}$ 전압을 정현파의 지수적 시간가중 소리레 벨과 관련시킨다. 즉 단기지속 자극음의 $\mathrm{b}-\mathrm{p}$ 또는 $\mathrm{p}-\mathrm{p}$ 전압을 기록한 후 해당 단기지속 자극음의 전압과 동일해질 때까지 레 벨이 조정된 연속 순음(일반적으로 $1,000 \mathrm{~Hz}$ )으로 대체된다. 그 후 이러한 단기지속 자극음의 peSPL은 사운드레벨미터에
서 고속 또는 저속 지수적 시간가중소리레벨 중 하나의 SPL 값 으로 표시된다. 따라서 이 방법은 $\mathrm{pSPL}$ 기능을 지원하는 사운 드레벨미터를 사용할 필요가 없다.

peSPL을 측정하는 방법은 b-p.e.SPL과 p-p.e.SPL을 측정 하는 방법으로 나눌 수 있는데, b-p.e.SPL 방법의 경우 클릭음 또는 다른 종류의 단기지속 자극음은 이어폰/커플러/마이크로 폰/사운드레벨미터를 통해 오실로스코프로 연결시킨다. 예를 들어, 단기지속 자극음을 제시한 후 오실로스코프에서 b-p 전 압을 측정한다. 사운드레벨미터의 음압 측정 범위를 변경하지 않은 상태에서 순음 자극을 이어폰을 통해 전달한 후 오실로 스코프의 b-p 전압이 단기지속 자극음의 baseline-to-peak 전 압과 동일해질 때까지 레벨을 조정한다. 이때 사운드레벨미터 의 판독 값이 바로 단기지속 자극음의 b-p.e.SPL이다. p-p. e.SPL 방법의 경우 오실로스코프에서 단기지속 자극음의 $\mathrm{p}-\mathrm{p}$ 전압을 측정하고, 정현파의 $\mathrm{p}-\mathrm{p}$ 전압이 단기지속 자극음의 $\mathrm{p}-\mathrm{p}$ 전압과 동일하게 될 때까지 정현파를 조정한다. 이 방법으로 사 운드레벨미터에 표시된 음압레벨은 단기지속 자극음의 $\mathrm{p}-\mathrm{p}$. e.SPL이라 한다. 이 정의에 대한 IEC 60645-3(2007)의 각주 (NOTE 3)를 살펴보면 기준 정현파(reference sinusoid)는 클릭 자극의 경우 $1,000 \mathrm{~Hz}$ 이어야 하고, 톤 버스트의 기준 정현파 주 파수는 톤 버스트의 주파수와 동일해야 한다. 단기지속 자극음 에 대한 상기 두 국제표준은 특별히 peSPL을 측정하는 방법으 로 피크 간 등가음압레벨을 사용하도록 권장한다.

b-p.e.SPL은 p-p.e.SPL보다 결코 작을 수 없다. 만약 클릭 음(또는 그 외 단기지속 자극음)의 양위상과 음위상의 전압이 동일한 경우 b-p.e.SPL과 p-p.e.SPL 값은 동일할 것이다. 클릭 음이 임계적으로 감쇠되어 있어(critically damped) 한 방향(양 위상 또는 음위상)으로만 전압의 편향(voltage deflection)을 보 이는 경우 b-p.e.SPL은 p-p.e.SPL보다 $6 \mathrm{~dB}$ 커질 것이다. 예 를 들어, 클릭음을 자극음으로 제시하여 사운드레벨미터의 아 날로그 출력에서 기록된 가장 큰 음의 전압[최대 음 전압(negative voltage)]은 $1 \mathrm{~V}$, 최대 양 전압(positive voltage)이 $0.4 \mathrm{~V}$ 라 고 가정해 보자. 이 경우 최대 $\mathrm{b}-\mathrm{p}$ 전압은 $1 \mathrm{~V}$ (예, 음 전압)이 며, 최대 $\mathrm{p}-\mathrm{p}$ 전압은 $1.4 \mathrm{~V}$ 이다. 그 후 $1,000-\mathrm{Hz}$ 정현파를 이어 폰으로 전송하고 $\mathrm{b}-\mathrm{p}$ 전압이 $1 \mathrm{~V}$ 가 될 때까지 $1,000-\mathrm{Hz}$ 정현 파의 레벨을 증가시킨다. 그 다음 사운드레벨미터의 저속 지수 적 시간가중평균방식을 이용하여 소리레벨을 측정해 음압을 판독하면 94-dB SPL이 나타날 것이다. 따라서 이 클릭음의 소 리레벨은 94-dB b-p.e.SPL임을 알 수 있다. 다음 단계로 p-p 전압이 $1.4 \mathrm{~V}$ 가 될 때까지 $1,000-\mathrm{Hz}$ 정현파의 레벨을 조절하 고, 사운드레벨미터의 화면에서 판독하는 경우 음압이 약 91 $\mathrm{dB}$ p-p.e.SPL임을 알 수 있다. 이와 같이 b-p.e.SPL과 p-p. e.SPL은 서로 동일한 값이 나타나지 않을 수도 있으며, 두 값 
모두 pSPL과는 다른 값이다. 따라서 pSPL은 항상 b-p.e.SPL 보다 $3 \mathrm{~dB}$ 더 크며, p-p.e.SPL은 b-p.e.SPL보다 $6 \mathrm{~dB}$ 정도까지 낮게 나타날 수 있음을 이해해야 한다. 희박상과 압축상 파의 진폭은 동일한 공진 시스템의 경우 b-p.e.SPL과 p-p.e.SPL이 동일할 수도 있지만 p-p.e.SPL은 b-p.e.SPL보다 결코 클 수는 없다. 즉, b-p.e.SPL과 p-p.e.SPL 값은 최대 $6 \mathrm{~dB}$ 정도 차이가 발생할 수 있기 때문에 peSPL의 측정 값을 기록할 경우 반드시 측정 기법을 보고해야만 한다.

\section{CONCLUSIONS}

청각전문가는 단기지속 자극음의 교정 및 필수 교정장비에 대한 전문지식을 보유하고 있어야 한다. 본 종설은 청성유발전 위 시스템을 정기적으로 교정하는 기술자 및 청각전문가에게 유용한 정보를 제공하기 위해 단기지속 자극음의 교정방법에 대해 소개하였다. 단기지속 자극음에 대한 국제표준에서는 특 별히 peSPL을 측정하는 방법으로 p-p.e.SPL을 사용하도록 권 장하고 있다. 국제표준에서 규정하고 있는 것처럼 $\mathrm{p}$-p.e.SPL 측정법이 pSPL 및 b-p.e.SPL 측정법보다 더 우수한 방법인지 생각해 볼 필요가 있다. Laukli \& Burkard(2015)는 "p-p.e.SPL 측정이 pSPL 또는 b-p.e.SPL보다 이점을 제공한다는 증거가 거의 없으며, b-p.e.SPL은 $3 \mathrm{~dB}$ 을 추가함으로써 pSPL로 항상 변환시킬 수 있고 혹은 반대로 $3 \mathrm{~dB}$ 을 감산함으로써 $\mathrm{pSPL}$ 을 b-p.e.SPL로 변환시킬 수 있기 때문에 p-p.e.SPL 사용이 항상 최선의 방법은 아니라고 주장하였다. 다른 한편으로는 다양한 종류의 이어폰 및 커플러의 b-p.e.SPL 및 p-p.e.SPL 사이의 숫자적 상관관계를 조사하여 b-p.e.SPL, p-p.e.SPL, pSPL 간 에 서로 쉽게 변환할 수 있는 변환 차트를 제공하는 방법도 있 으나 pSPL을 채택함으로써 간단히 해결될 수 있는 문제를 더 복잡하게 만드는 것이라 주장하였다. 또한 pSPL 또는 peSPL 이 RETSPL을 측정하는 최상의 방법이라는 증거도 거의 없으 며, 특히 클릭음의 경우 첫 번째 주기 동안 균일한 가중치가 적 용된 음압레벨(uniform-weighted SPL)이 위의 레벨보다 더 좋은 측정법일 수도 있다”고 하였다.

현재 ISO 389-6(2007)에서는 표준 톤 버스트 또는 클릭음에 대한 기준등가역치음압강도만 규정되어 있다. 초기 청성유발전 위에 주로 이용되는 2-1-2 주기의 톤 버스트보다 상승시간과 총 지속시간이 더 긴 후기 청성유발전위에 사용되는 톤 버스트 및 어음자극, 그리고 청성지속반응을 유발하는 데 사용되는 다 양한 종류의 변조 자극에 대한 표준도 개발해야 할 필요가 있 다. 특히 현재 다양한 집단에서 실험적으로 연구되고 있는 chirp 음(광대역 및 주파수 제한 chirps 음)의 RETSPL도 표준 화되어야 한다.
본 종설에서 다룬 단기지속 자극음의 전반적인 레벨뿐 아니 라 신호가 청력검사용 출력장치를 통해 재생될 때 해당 신호의 주파수 특성을 확인해야 한다. 신호의 음향 스펙트럼은 전기신 호의 스펙트럼과 반드시 동일하지는 않다. 그 이유는 각각의 시 스템이 고유의 전달 함수를 가지고 있으며, 자극음의 음향 스펙 트럼은 이어폰 및 사운드레벨미터의 마이크로폰과 이어폰을 연 결하는 커플러에 영향을 받기 때문이다.

중심 단어 : 청성유발전위·단기지속 자극음·피크 간 등가음압 레벨·행동학적 교정·물리적 교정.

\section{REFERENCES}

Beattie, R. C. \& Rochverger, I. (2001). Normative behavioral thresholds for short tone-bursts. Journal of the American Academy of Audiology 12(9), 453-461.

Burkard, R. (1984). Sound pressure level measurement and spectral analysis of brief acoustic transients. Electroencephalography and Clinical Neurophysiology, 57(1), 83-91.

Burkard, R. F., Don, M., \& Eggermont, J. J. (2007). Auditory Evoked Potentials: Basic Principles and Clinical Application. (1st ed). (pp. 229-253). Baltimore, MD: Lippincott Williams \& Wilkins.

Davis, H., Hirsh, S. K., Popelka, G. R., \& Formby, C. (1984). Frequency selectivity and thresholds of brief stimuli suitable for electric response audiometry. Audiology, 23(1), 59-74.

Fedtke, T. \& Richter, U. (2007). Reference zero for the calibration of airconduction audiometric equipment using 'tone bursts' as test signals. International Journal of Audiology, 46(1), 1-10.

Haughton, P. (2006). Insert earphones--a comparison of short-duration signals measured with an occluded ear simulator and a $2 \mathrm{cc}$ coupler. International Journal of Audiology, 45(1), 60-65.

Hirsh, I. J. (1975). Temporal aspects of hearing. In Tower, D. B. (1st ed). The Nervous System, Human Communication and Its Disorders, Vol. 3. (pp. 157-162). New York, NY: Raven Press.

IEC 60318-1. (2009). Electroacoustics-Simulators of Human Head and Ear -Part 1: Ear Simulator for the Measurement of Supra-Aural and Circumaural Earphones. Geneva, International Electrotechnical Commission.

IEC 60318-4. (2010). Electroacoustics-Simulators of Human Head and Ear -Part 4: Occluded-Ear Simulator for the Measurement of Earphones Coupled to the Ear by Means of Ear Inserts. Geneva, International Electrotechnical Commission.

IEC 60318-5. (2006). Electroacoustics-Simulators of Human Head and Ear -Part 5: $2 \mathrm{~cm}^{3}$ Coupler for the Measurement of Hearing Aids and Earphones Coupled to the Ear by Means of Ear Inserts. Geneva, International Electrotechnical Commission.

IEC 60645-3. (2007). Electroacoustics-Audiometric Equipment-Part 3: Test Signals of Short Duration. Geneva, International Electrotechnical Commission.

IEC 60645-7. (2009). Electroacoustics-Audiometric Equipment-Part 7: Instruments for the Measurement of Auditory Brainstem Responses. Geneva, International Electrotechnical Commission.

ISO 389-6. (2007). Acoustics--Reference Zero for the Calibration of Audiometric Equipment--Part 6: Reference Threshold of Hearing for Test Signals of Short Dduration. Geneva, International Organization for Standardization.

ISO 389-9. (2009). Acoustics--Reference Zero for the Calibration of Audiometric Equipment--Part 9: Preferred Test Conditions for the Determination of Reference Hearing Threshold Levels. Geneva, International Organization for Standardization. 
Jacobson, J. T. (1994). Principles and Applications in Auditory Evoked Potentials. (1st ed). (pp. 85-97). Boston, MA: Allyn \& Bacon.

Katz, J. (2002). Handbook of Clinical Audiology. (5th ed). (pp. 233-248). Baltimore, MD: Lippincott Williams \& Wilkins.

Katz, J., Burkard. R. F., \& Medwetsky L. (2009). Handbook of Clinical Audiology. (6th ed). (pp. 222-241). Baltimore, MD: Lippincott Williams \& Wilkins.

Kim, J. D. (2016a). Audiometric calibration of pure tone audiometers. Audiology and Speech Research, 12(1), 12-23.

Kim, J. D. (2016b). Audiometric calibration of pure tone audiometers. Audiology and Speech Research, 12(3), 127-138.

Kim, J. D. (2016c). Audiometric calibration of aural acoustic immittance instrument: A review of acoustic immittance instrument's calibration. Biomedical Science Letters, 22, 115-126.

Laukli, E. \& Burkard, R. (2015). Calibration/standardization of short-duration stimuli. Seminars in Hearing, 36(1), 3-10.

Lightfoot, G., Sininger, Y., Burkard, R., \& Lodwig, A. (2007). Stimulus repetition rate and the reference levels for clicks and short tone bursts: A warning to audiologists, researchers, calibration laboratories, and equip- ment manufacturers. American Journal of Audiology, 16(2), 94-95.

Pedersen, C. B. \& Elberling, C. (1972). Temporal integration of acoustic energy in normal hearing persons. Acta Oto-Laryngologica, 74(6), 398405.

Picton, T. W., Woods, D. L., Baribeau-Rraun, J., \& Healey, T. M. (1976). Evoked potential audiometry. The Journal of Otolaryngology, 6(2), 90119 .

Richter, U. \& Fedtke, T. (2005). Reference zero for the calibration of audiometric equipment using 'clicks' as test signals. International Journal of Audiology, 44(8), 478-487.

Stapells, D. R., Picton, T. W., \& Smith, A. D. (1982). Normal hearing thresholds for clicks. The Journal of the Acoustical Society of America, 72(1), 74-79.

Yeager, D. M. \& Marsh. A. H. (1991). Sound levels and their measurement. In Harris, C. M. (3rd ed). Handbook of Acoustical Measurements and Noise Control (pp. 1-18). New York, NY: McGraw-Hill.

Yost, W. A. \& Klein, A. J. (1979). Thresholds of filtered transients. Audiolo$g y, 18(1), 17-23$. 